\title{
Slow release carbamazepine in treatment of poorly controlled seizures
}

\author{
S W Ryan, I Forsythe, R Hartley, M Haworth, C J Bowmer
}

\begin{abstract}
Thirty three children with poorly controlled epilepsy, and six new patients, were treated with slow release carbamazepine. Twelve of the former had a reduction in the number of seizures of more than half, and $\mathbf{1 0}$ had fewer side effects. Three of the new patients stopped having seizures. Variations in plasma concentrations between doses was significantly less when patients took the slow release preparation (22\%) compared with the standard preparation (41\%). Slow release carbamazepine may improve the conditions of children whose seizures are poorly controlled.
\end{abstract}

Carbamazepine is the first choice of drug for the treatment of children with tonic-clonic and complex partial seizures. ${ }^{1-4}$ Giving treatment twice daily has been recommended to simplify administration, aid compliance, and avoid the necessity of teachers having to dispense the drug during school hours. ${ }^{356}$ We have shown, however, that because of the short half life of carbamazepine, there is a significant difference in plasma carbamazepine concentrations between the maximum (peak) and the minimum (trough) in patients receiving doses twice daily. ${ }^{7}$ Experience has shown that seizures are more likely to occur during troughs, particularly in the morning on awakening, whereas side effects are often associated with peaks. ${ }^{8}{ }^{9}$

Until the recent introduction of slow release preparations of carbamazepine the only way of diminishing the effects of troughs and peaks was to increase the number of doses. This presented difficulties in dispensing the drug at school, and lead to poorer patient compliance. $^{356}$ Despite minimising plasma fluctuations during the day by this approach, the problem of dividing doses equally during the night remains. As this is not practicable because of children's sleeping patterns, the early morning troughs persist. Furthermore, attempts to vary the dose during the day to take account of the irregular dosing intervals, may lead to confusion among patients and paediatricians.

A slow release preparation should, however, provide a smoother plasma concentration-time profile, with smaller peaks and shallower troughs, thus permitting twice daily dosage. In view of the increased cost of such a preparation it is important to assess its clinical effectiveness and its pharmacokinetic profile. If these are satisfactory, the preparation would be a useful addition to the anticonvulsant formulary.

Consequently, when slow release carbamaze- pine became available (Tegretol CR Divitabs, Ciba Geigy) we assessed its effects.

\section{Patients and methods}

The study was approved by the hospital ethics committee. Thirty three children with poorly controlled epilepsy who were suffering from generalised tonic-clonic $(n=25)$ or complex partial seizures $(n=8)$ were identified during a one year period. In addition six new patients with tonic-clonic seizures who had not yet received treatment were also studied. They all started drug treatment if three seizures, each of more than five minutes duration, had occurred during a period of six months. When such children were identified the study was explained to the parents and child and consent obtained. There were no refusals.

All 33 children with poorly controlled seizures had received standard carbamazepine twice daily, and later some had been given carbamazepine and acetazolamide, sodium valproate, mysoline, bromide, or phenytoin (table 1). In patients who had previously been treated with carbamazepine, the dosage of slow release carbamazepine/kg body weight that was given was similar to the previous dose, except for two patients, in whom the previous dose was felt to be inadequate and so a higher dose of slow release carbamazepine was prescribed.

Those receiving acetazolamide were allowed to continue, as we regarded it as unethical to discontinue it at this stage. Patients on other drugs were changed over a period of two to three weeks to slow release carbamazepine.

After the patients had been treated for 30 to 100 days they were admitted overnight so that blood samples could be taken to provide measurements of the pharmacokinetic profile of the slow release preparation. The skin was anaesthetised with $2 \cdot 5 \%$ lignocaine and prilocaine cream (Emla, Astra), and an indwelling venous cannula was inserted. At 2000 the first sample was taken to assess compliance. The following day samples were taken at hourly intervals (0800-1200) and then every two hours until 2000. On each occasion a $3 \mathrm{ml}$ sample was obtained after adequate flushing of the cannula to avoid dilution with heparin; samples were then stored at $4^{\circ} \mathrm{C}$ for 36 hours before separation.

Plasma concentrations of carbamazepine were measured by an established method with high performance liquid chromatography. ${ }^{10}$ Mean peak and trough plasma concentrations of carbamazepine were calculated and the interdose fluctuations were calculated as the percentage
Correspondence to: Dr Ryan.

Accepted 12 April 1990 
Table 1 Details of patients studied

\begin{tabular}{|c|c|c|c|c|c|c|}
\hline $\begin{array}{l}\text { Case } \\
\text { No }\end{array}$ & Sex & $\begin{array}{l}\text { Age } \\
\text { (years) }\end{array}$ & $\begin{array}{l}\text { Weight } \\
\text { (kg) }\end{array}$ & Previous drugs, dose, and timing & $\begin{array}{l}\text { Initial dose of slow } \\
\text { release carbamazepine } \\
\text { (twice a day, mg) }\end{array}$ & Other features \\
\hline \multicolumn{7}{|c|}{ Children with tonic-clonic seizures: } \\
\hline $\begin{array}{r}1 \\
2 \\
3 \\
4 \\
5 \\
6 \\
7 \\
8 \\
9 \\
10 \\
11 \\
12 \\
13 \\
14 \\
15 \\
16 \\
17 \\
18\end{array}$ & $\begin{array}{l}\text { Male } \\
\text { Female } \\
\text { Female } \\
\text { Female } \\
\text { Male } \\
\text { Female } \\
\text { Male } \\
\text { Female } \\
\text { Female } \\
\text { Male } \\
\text { Female } \\
\text { Female } \\
\text { Female } \\
\text { Male } \\
\text { Male } \\
\text { Male } \\
\text { Male } \\
\text { Male }\end{array}$ & $\begin{array}{r}4 \\
4 \\
5 \\
5 \\
6 \\
7 \\
7 \\
8 \\
9 \\
9 \\
10 \\
10 \\
10 \\
10 \\
10 \\
10 \\
11 \\
11\end{array}$ & $\begin{array}{l}20 \\
17 \\
29 \cdot 5 \\
25 \\
32 \\
40 \cdot 5 \\
24 \\
23 \\
38 \\
34 \\
32 \\
29 \\
40 \\
39 \\
32 \\
31 \\
23 \\
46 \cdot 5\end{array}$ & $\begin{array}{l}\text { Carbamazepine } 200 \mathrm{mg} \text { twice a day } \\
\text { Carbamazepine } 200 \mathrm{mg} 3 \text { times a day } \\
\text { Mysoline } 125 \mathrm{mg} 3 \text { times a day } \\
\text { Carbamazepine } 150,100 \text {, and } 200 \mathrm{mg} \\
\text { Carbamazepine } 200 \mathrm{mg} 3 \text { times a day } \\
\text { Phenytoin } 100 \mathrm{mg} \text { twice a day } \\
\text { Bromide } \\
\text { Carbamazepine } 150 \mathrm{mg} 3 \text { times a day } \\
\text { Sodium valproate } 200 \mathrm{mg} \text { times a day } \\
\text { Carbamazepine } 300 \mathrm{mg} 3 \text { times a day } \\
\text { Carbamazepine } 200 \mathrm{mg} 3 \text { times a day } \\
\text { Carbamazepine } 200 \mathrm{mg} 3 \text { times a day } \\
\text { Mysoline } 250 \mathrm{mg} 3 \mathrm{times} \text { a day } \\
\text { Carbamazepine } 200,200 \text {, and } 400 \mathrm{mg} \\
\text { Carbamazepine } 200 \mathrm{mg} \text { twice a day } \\
\text { Carbamazepine } 100 \mathrm{mg} \text { times a day } \\
\text { Carbamazepine } 150 \mathrm{mg} 3 \text { times a day } \\
\text { Carbamazepine } 800,600 \text {, and } 600 \mathrm{mg} \text {, }\end{array}$ & $\begin{array}{r}200 \\
300 \\
300 \\
200 \\
300 \\
400 \\
200 \\
200 \\
300 \\
400 \\
300 \\
200 \\
400 \\
500 \\
200 \\
300 \\
200 \\
1000\end{array}$ & $\begin{array}{l}\text { Mental retardation } \\
\text { Atonic } \\
\text { None } \\
\text { None } \\
\text { None } \\
\text { Atonic } \\
\text { Focal right sided seizures } \\
\text { Focal left sided seizures } \\
\text { None } \\
\text { None } \\
\text { Atonic } \\
\text { Focal left sided seizures } \\
\text { None } \\
\text { Left hemiplegia } \\
\text { None } \\
\text { Tuberous sclerosis } \\
\text { Spastic quadriplegia } \\
\text { Operation to frontal lobe }\end{array}$ \\
\hline $\begin{array}{l}19 \\
20 \\
21 \\
22 \\
23 \\
24 \\
25\end{array}$ & $\begin{array}{l}\text { Male } \\
\text { Male } \\
\text { Male } \\
\text { Female } \\
\text { Male } \\
\text { Female } \\
\text { Male }\end{array}$ & $\begin{array}{l}12 \\
12 \\
14 \\
14 \\
15 \\
16 \\
16\end{array}$ & $\begin{array}{l}57 \\
45 \\
52 \\
62 \\
60 \\
48 \\
\text { Not known }\end{array}$ & $\begin{array}{l}\text { Carbamazepine } 200,200 \text {, and } 400 \mathrm{mg} \\
\text { Carbamazepine } 200,200 \text {, and } 400 \mathrm{mg} \\
\text { Carbamazepine } 400,200 \text {, and } 600 \mathrm{mg} \\
\text { Carbamazepine } 200 \mathrm{mg} \text { twice a day } \\
\text { Carbamazepine } 400 \mathrm{mg} \text { times a day } \\
\text { Carbamazepine } 400 \mathrm{mg} \text { twice a day } \\
\text { Carbamazepine } 500 \mathrm{mg} \text { twice a day }\end{array}$ & $\begin{array}{l}400 \\
400 \\
600 \\
100 \\
600 \\
500 \\
500\end{array}$ & $\begin{array}{l}\text { None } \\
\text { Hemiplegia } \\
\text { None } \\
\text { None } \\
\text { None } \\
\text { None } \\
\text { Focal right sided seizures }\end{array}$ \\
\hline \multicolumn{7}{|c|}{ Children with complex partial seizures: } \\
\hline $\begin{array}{l}26 \\
27 \\
28 \\
29 \\
30\end{array}$ & $\begin{array}{l}\text { Male } \\
\text { Male } \\
\text { Female } \\
\text { Male } \\
\text { Female }\end{array}$ & $\begin{array}{r}5 \\
8 \\
9 \\
11 \\
12\end{array}$ & $\begin{array}{l}22 \\
23 \\
35 \cdot 5 \\
46 \cdot 5 \\
48\end{array}$ & $\begin{array}{l}\text { Carbamazepine } 200 \text { and } 300 \mathrm{mg} \\
\text { Carbamazepine } 200 \mathrm{mg} \text { twice a day } \\
\text { Carbamazepine } 400 \text { and } 800 \mathrm{mg} \\
\text { Carbamazepine } 200,200 \text {, and } 400 \mathrm{mg} \\
\text { Carbamazepine } 300 \mathrm{mg} 3 \text { times a day, } \\
\text { and acetazolamide }\end{array}$ & $\begin{array}{l}200 \\
200 \\
600 \\
400 \\
500\end{array}$ & $\begin{array}{l}\text { Hemiplegia } \\
\text { None } \\
\text { None } \\
\text { None } \\
\text { None }\end{array}$ \\
\hline $\begin{array}{l}31 \\
32 \\
33\end{array}$ & $\begin{array}{l}\text { Female } \\
\text { Female } \\
\text { Female }\end{array}$ & $\begin{array}{l}13 \\
14 \\
14\end{array}$ & $\begin{array}{l}52 \cdot 5 \\
47 \\
39\end{array}$ & $\begin{array}{l}\text { Sodium valproate } 700 \mathrm{mg} \text { twice a day } \\
\text { Carbamazepine } 200 \mathrm{mg} \text { twice a day } \\
\text { Carbamazepine } 200 \mathrm{mg} 3 \text { times a day }\end{array}$ & $\begin{array}{l}600 \\
200 \\
600\end{array}$ & $\begin{array}{l}\text { None } \\
\text { None } \\
\text { None }\end{array}$ \\
\hline
\end{tabular}

decrease from peak to trough concentration (100(peak-trough)/peak).

Comparison of the mean peak (1200) and trough (2000) concentrations were made with Student's $t$ test for paired samples. In addition the mean peak and trough concentrations from a subgroup of 16 patients receiving a daily dose of 14 to $20 \mathrm{mg} /$ day slow release carbamazepine were compared with the corresponding concentrations in children taking similar doses of standard carbamazepine. The interdose fluctuation in concentrations obtained from the subgroup of patients receiving slow release carbamazepine was also compared with that in children taking the standard preparation. In all cases comparisons of mean carbamazepine plasma concentrations and the interdose fluctuations between patients receiving slow release carbamazepine or the standard preparation were made with Student's $t$ test for unpaired samples.

Once the plasma carbamazepine concentrations had been calculated, the patients' responses were analysed. If seizures recurred, the dose was increased (provided that plasma carbamazepine concentration indicated that this was reasonable), or they were changed back to their original preparation, or they were given a different preparation (for example, oxcarbazepine). Results of the adjustments and changes in treatment are shown in tables 2 and 3 .

All parents and patients were asked to keep an accurate record of seizures, and in the group of poorly controlled children, diaries were well kept. Each time a patient was seen at the clinic the number, type, duration, and severity of seizures was recorded by the doctor.
When the study was completed the duration of treatment and the number of seizures were noted. An equal retrospective time period from the onset of the medication change was also noted, and the number of seizures occurring during that period was recorded for comparison. In this way we hoped to assess any therapeutic benefit of the new preparation. The length of periods of observation are shown in tables 2 and 3.

In addition, parents were asked to note any change that occurred in their child after the drug was changed to identify benefits as well as adverse side effects.

\section{Results}

\section{SEIZURES}

The results for individual patients are shown in table 2 . Of 25 patients with poorly controlled tonic-clonic seizures, five ( $20 \%$ ) had no seizures while taking slow release carbamazepine (although two had had no seizures in either the treatment or the control period); in six (24\%) the number of seizures was reduced by more than half; nine (36\%) showed no change in their seizure pattern; in one (4\%) the frequency of seizures increased by more than half; and in four $(16 \%)$ the frequency more than doubled. Thirteen patients $(52 \%)$ remained on unadjusted doses of slow release carbamazepine, four $(16 \%)$ had their doses increased, two $(8 \%)$ were given acetazolamide in addition, two (8\%) reverted to their original treatment, and four (16\%) received new forms of treatment including two $(8 \%)$ who were prescribed oxcarbaze- 
pine. All four patients who had their doses of slow release carbamazepine increased had a decrease in the frequency of seizures.

Of the eight patients with complex partial seizures, one had complete control of seizures (but was also free of seizures in the control period); in three $(37 \%)$ the number of seizures was reduced by between a half and three quarters; four $(50 \%)$ were unchanged, and one was worse. Five patients remained on slow release carbamazepine and two of these had the dose increased without further improvement in seizure control.

Of the six new patients who were given slow release carbamazepine, three were free of seizures on follow up after 62 to 182 days, having previously had between two and four seizures during the control period (table 3 ). One patient experienced pronounced deterioration in seizure control (from one seizure in 136 days dur- ing the control period to 195 seizures during the period of treatment). This patient's condition however, constantly changed after a cerebral infarct, and other treatments were equally ineffective.

\section{SIDE EFFECTS}

Of the 33 patients, $10(30 \%)$ experienced some side effects. In seven $(21 \%)$ transient diplopia, vertigo, or bad temper were noted. Only three patients $(9 \%)$ had persistent adverse side effects, and in two of these treatment was discontinued. One patient experienced screaming and photophobia, the other slurred speech and ataxia. The remaining patient complained of tiredness, which persisted, but elected to continue treatment as the seizures were controlled. In this patient trough and peak plasma concen-

Table 2 Number of seizures that occurred when patients changed to slow release carbamazepine compared with the number that occurred when taking previous treatment over a comparable period, and further changes in treatment made during the study

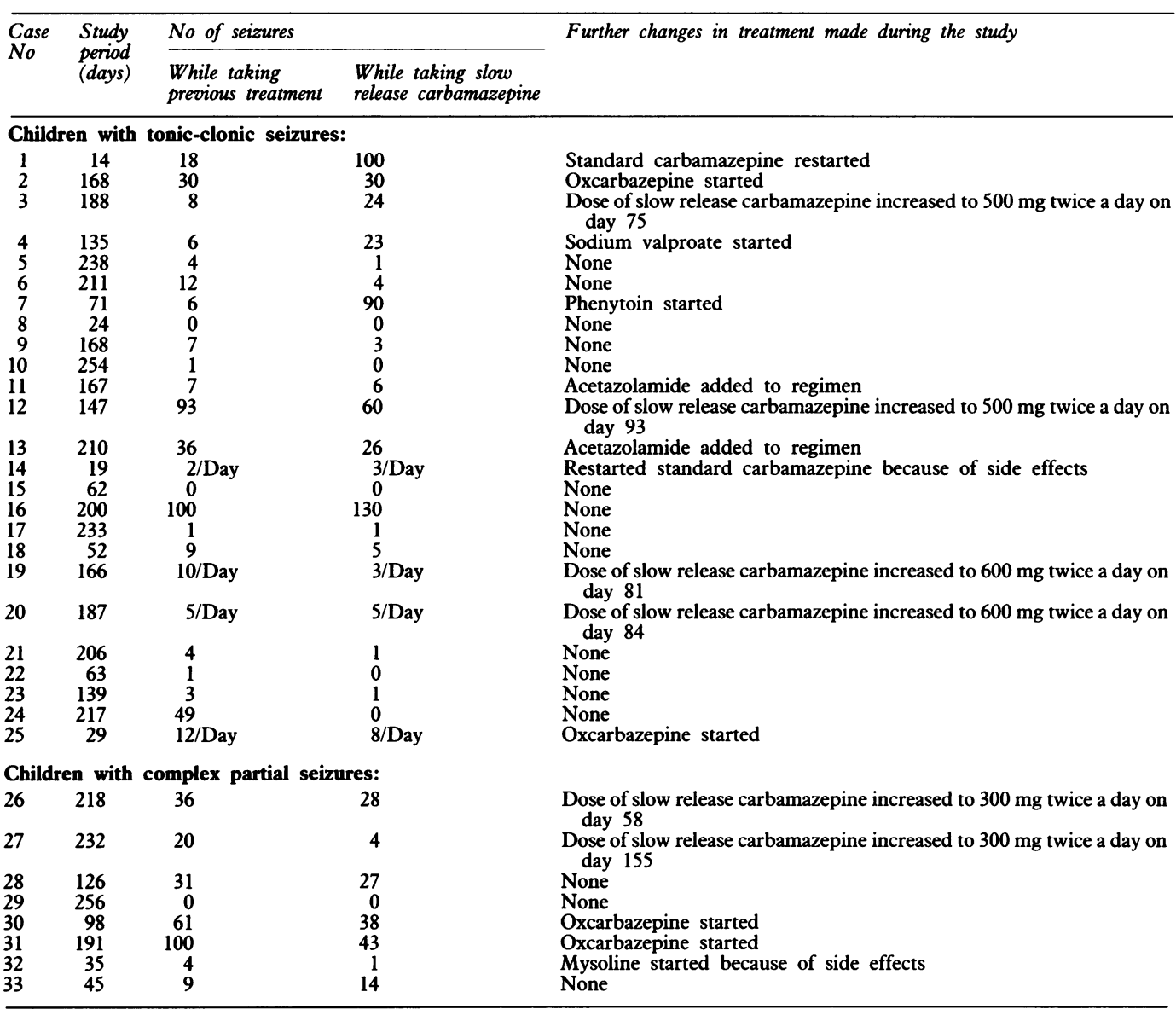

Table 3 Details of six patients with tonic-clonic seizures who received slow release carbamazepine as their first anticonvulsant treatment

\begin{tabular}{|c|c|c|c|c|c|c|c|c|}
\hline \multirow{2}{*}{$\begin{array}{l}\text { Case } \\
\text { No }\end{array}$} & \multirow[t]{2}{*}{ Sex } & \multirow{2}{*}{$\begin{array}{l}\text { Age } \\
\text { (years) }\end{array}$} & \multirow{2}{*}{$\begin{array}{l}\text { Weight } \\
(\mathrm{kg})\end{array}$} & \multirow{2}{*}{$\begin{array}{l}\text { Dose (twice } \\
\text { a day) }\end{array}$} & \multirow{2}{*}{$\begin{array}{l}\text { Study period } \\
\text { (days) }\end{array}$} & \multicolumn{2}{|c|}{ No of seizures } & \multirow{2}{*}{$\begin{array}{l}\text { Changes made in treatment } \\
\text { during period of study }\end{array}$} \\
\hline & & & & & & $\begin{array}{l}\text { Before } \\
\text { treatment }\end{array}$ & $\begin{array}{l}\text { After starting } \\
\text { treatment }\end{array}$ & \\
\hline $\begin{array}{l}34 \\
35 \\
36\end{array}$ & $\begin{array}{l}\text { Male } \\
\text { Female } \\
\text { Male }\end{array}$ & $\begin{array}{r}13 \\
11 \\
9\end{array}$ & $\begin{array}{l}55 \cdot 5 \\
43 \\
20\end{array}$ & $\begin{array}{l}600 \\
400 \\
200\end{array}$ & $\begin{array}{r}182 \\
62 \\
7\end{array}$ & $\begin{array}{l}2 \\
2 \\
\text { Study pe } \\
\text { assess }\end{array}$ & $\begin{array}{l}0 \\
0 \\
\text { d too short to }\end{array}$ & $\begin{array}{l}\text { None } \\
\text { None } \\
\text { Sodium valproate started }\end{array}$ \\
\hline $\begin{array}{l}37 \\
38 \\
39\end{array}$ & $\begin{array}{l}\text { Female } \\
\text { Male } \\
\text { Male }\end{array}$ & $\begin{array}{r}7 \\
4 \\
15\end{array}$ & $\begin{array}{l}28 \cdot 5 \\
25 \\
58 \cdot 4\end{array}$ & $\begin{array}{l}300 \\
300 \\
400\end{array}$ & $\begin{array}{r}85 \\
136 \\
7\end{array}$ & $\begin{array}{l}4 \\
1 \\
\text { Study pe } \\
\text { assess }\end{array}$ & $\begin{array}{l}0 \\
195 \\
\text { quency } \\
\text { quen short to }\end{array}$ & $\begin{array}{l}\text { None } \\
\text { Phenytoin started } \\
\text { Phenytoin started }\end{array}$ \\
\hline
\end{tabular}


trations of carbamazepine were 35.9 and $47 \cdot 4$ $\mu \mathrm{mol} / \mathrm{l}$, respectively. Beneficial side effects were observed in 10 patients, these included improved behaviour and school performance, less vertigo, and less sedation (six had changed from standard carbamazepine, and four from other drugs).

Of the six new patients who were treated with slow release carbamazepine, two developed rashes, and treatment was discontinued. The rash in one persisted on sodium valproate and was eventually diagnosed as acne with follicular eczema.

In all, 14 of the 33 patients (42\%) who had previously received anticonvulsant treatment (reduced frequency of seizures in 12 , reduced side effects in 10) and three new patients obtained some benefit from treatment with slow release carbamazepine.

PLASMA CONCENTRATIONS OF CARBAMAZEPINE Of the 39 children recruited into the study, 28 satisfied the criteria for inclusion of data on plasma concentrations for statistical analysis. Eleven patients were not included because two were receiving acetazolamide, four changed treatment before analysis, and in five patients samples were not available at a suitable time. Consequently, in 28 patients taking slow release carbamazepine (mean (SD) daily dose 19.3 (5.4) $\mathrm{mg} / \mathrm{kg}$ ) the mean (SD) peak plasma concentration at 1200 was $37 \cdot 3(7 \cdot 5) \mu \mathrm{mol} / \mathrm{l}$ and mean (SD) trough concentrations were $33.3(9 \cdot 1)$ and $29 \cdot 4(7 \cdot 6) \mu \mathrm{mol} / 1$ at 0800 and 2000 , respectively. The differences between peak and trough concentrations of carbamazepine were significant $(p<0.001)$. Similar peak and trough values for plasma carbamazepine were calculated for 16 children who received between 14 and 20 $\mathrm{mg} / \mathrm{kg} /$ day of slow release carbamazepine (mean $17 \cdot 7(1 \cdot 8) \mathrm{mg} / \mathrm{kg} /$ day $)$. These values were compared with those obtained in 18 children receiving a standard formulation of carbamazepine in the same dose range $(16.9(1 \cdot 7) \mathrm{mg} / \mathrm{kg} /$ day $)$ (table 4). Comparisons of these mean plasma concentrations between treatment groups showed no significant difference between peaks ( $p>0.05$ ), but troughs were significantly lower $(\mathrm{p}<0.01$ and $\mathrm{p}<0.05$ at 0800 and 2000 , respec-

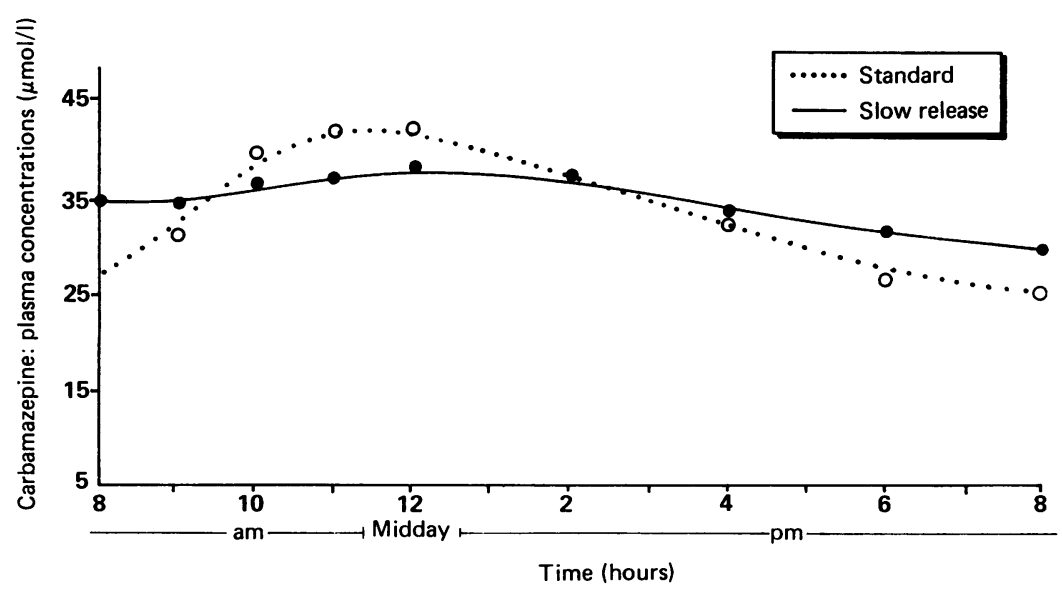

Plasma concentrations of carbamazepine in children treated with comparable doses (14 to $20 \mathrm{mg} / \mathrm{kg} /$ day) of standard and slow release carbamazepine.
Table 4 Plasma concentrations of carbamazepine in children receiving comparable doses of standard compared with slow release preparations in the dose range 14-20 $\mathrm{mg} / \mathrm{kg} /$ day

\begin{tabular}{llll}
\hline Time & \multicolumn{2}{l}{$\begin{array}{l}\text { Mean }(S D) \\
\text { concentration }(\mu \text { mol/l) }\end{array}$} & p Value \\
\cline { 2 - 4 } & $\begin{array}{l}\text { Slow release } \\
(n=16)\end{array}$ & $\begin{array}{l}\text { Standard } \\
(n=18)\end{array}$ & \\
\hline 0800 (trough) & $34 \cdot 6(7 \cdot 9)$ & $26 \cdot 8(4 \cdot 3)$ & $<0.01$ \\
1200 (peak) & $38 \cdot 1(7 \cdot 0)$ & $42.3(6.8)$ & $>0.05$ \\
2000 (trough) & $29.9(7 \cdot 6)$ & $25 \cdot 2(4 \cdot 9)$ & $<0.05$ \\
\hline
\end{tabular}

tively) in the group of patients receiving standard carbamazepine. The interdose variation in carbamazepine plasma concentrations was $21 \cdot 3 \%$ for the total population of 28 receiving slow release carbamazepine, $21 \cdot 5 \%$ for the subgroup of 16 patients receiving 14 to 20 $\mathrm{mg} / \mathrm{kg} /$ day of slow release carbamazepine, and $41 \%$ for the 18 patients receiving comparable doses of the standard carbamazepine preparation.

The carbamazepine peak:trough plasma level ratio was 1.27 for slow release carbamazepine in both the total group of patients and the subgroup of 16 patients who were receiving doses ranging from 14 to $20 \mathrm{mg} / \mathrm{kg} /$ day. In 18 patients treated with the standard carbamazepine preparation in comparable doses (14 to 20 $\mathrm{mg} / \mathrm{kg} /$ day), however, the ratio was $1 \cdot 68$.

\section{Discussion}

For the purpose of this discussion slow release carbamazepine-CG refers to Ciba Geigy carbamazepine (Tegretol CR Divitabs), slow release carbamazepine-D to Desitin carbamazepine (Timonil Retard), and slow release carbamazepine-F to Farmos Group Limited carbamazepine (Neurotol Slow). In a group of children selected because of their difficulty in controlling seizures, benefit was obtained in $36 \%$ on changing to slow release carbamazepine-CG. Half of six new patients treated with this preparation were also well controlled. The only other study that reports the clinical effectiveness of slow release carbamazepine found that 11 out of 18 children were improved by the use of slow release carbamazepine-D once daily (M Albani, B Sehringer-Mansour, unpublished observations); four of the patients became free of seizures and seven had diminished frequency of seizures. The outcome in six of the patients was not recorded, however, and in addition 13 of the 18 patients studied were taking several other drugs that were continued during treatment with slow release carbamazepine- $D$, so that it is impossible to assess fully the value of slow release carbamazepine-D in this study.

Some adult studies that reported no change in the frequency of seizures in patients who were changed to slow release carbamazepine-CG or slow release carbamazepine-F were too short to be valid. ${ }^{11} 12$ One study showed complete control of seizures in $42 \%$ of adults changed from various anticonvulsant regimens to slow release carbamazepine-D, once daily, with reduced frequency of seizures in $16 \%$. ${ }^{13}$ Slow release carbamazepine-D seemed to be most effective in 
patients who had previously been receiving carbamazepine alone or in combination, and in patients affected only with tonic-clonic seizures Our study of complex partial seizures was too small to differentiate response according to type of seizure.

Adverse side effects were observed in $30 \%$ of the children included in this study, but in most cases they were transient and tolerable so that it was necessary to discontinue treatment with slow release carbamazepine-CG in only two patients. Slow release carbamazepine-D has been reported to cause fewer side effects in children who had previously received carbamazepine alone or in combination ( $M$ Albani, B Sehringer-Mansour, unpublished observations), but some short studies in adult patients have reported no difference in side effects between treatment with standard carbamazepine and with slow release carbamazepine-CG and slow release carbamazepine-F. ${ }^{13}{ }^{14}$ Others have found that slow release carbamazepine-CG had a diminished effect on cognitive function compared with standard carbamazepine, although side effects still persisted in $17 \%$ of adult patients treated with slow release carbamazepine-CG. ${ }^{13}$ Compared with standard carbamazepine preparations, however, slow release carbamazepine-F produced similar side effects, ${ }^{14}$ and slow release carbamazepine-CG similar psychomotor function in healthy adult volunteers. ${ }^{15}$

In both children and adults cognitive function is impaired by higher serum concentrations of carbamazepine, ${ }^{16}{ }^{17}$ and other side effects are seen more often when blood concentrations of carbamazepine are above $36 \mu \mathrm{mol} / 1 .^{8}{ }^{18}$ Using slow release carbamazepine-CG we were able to give higher doses with less risk of side effects than with the standard preparation. In six of our patients the doses were increased in excess of 30 $\mathrm{mg} / \mathrm{kg} /$ day though none of these children experienced adverse side effects. Other authors have had similar experiences ( $M$ Albani, B Sehringer-Mansour, unpublished observations). This finding has important implications: the recommended dose range for slow release carbamazepine can be greater, with a maximum of about $30 \mathrm{mg} / \mathrm{kg} / \mathrm{day}$. Once the patient is on the higher dose of slow release carbamazepine he or she should not be changed automatically to the same dose of standard carbamazepine, as this could lead to adverse side effects.

As with standard carbamazepine, the time to achieve peak plasma concentration with slow release carbamazepine-CG was in the region of four hours. Similar observations have been reported for slow release carbamazepine-F, ${ }^{12}$ $D,{ }^{18}$ and CG. ${ }^{1619}$ The pharmacokinetic profile obtained using slow release carbamazepine-CG, however, was considerably smoother compared with the standard preparation (figure): the interdose variation was reduced by a factor of two by a $10 \%$ reduction in the mean peak carbamazepine plasma concentration combined with a $20-30 \%$ increase in mean trough concentration. The interdose variation found with slow release carbamazepine-CG in this study is comparable with results from previous studies using slow release carbamazepine-CG, ${ }^{16}$ slow release
carbamazepine-D, ${ }^{18}$ and slow release carbamazepine-F ${ }^{12}$ using twice daily doses. The degree of fluctuation, however, was reported to be much larger when slow release carbamazepine-D was given once daily. ${ }^{13}$ Reduced interdose variation in carbamazepine concentrations does not seem to be at the expense of bioavailability, as on slow release carbamazepine-CG twice daily the mean area under the carbamazepine concentration-time curve is not significantly different from the standard preparation (R Hartley, S W Ryan, I Forsythe, et al, unpublished observations); this is consistent with earlier reports. ${ }^{11} 16$ The mean carbamazepine peak:trough plasma concentration ratio was 1.68 in children receiving standard carbamazepine, which was reduced by $24 \%$ to $1 \cdot 27$ using slow release carbamazepine-CG. The lower value $(1 \cdot 27)$ compares favourably with figures obtained with other preparations, ${ }^{12} 1318$ and indicates that slow release carbamazepine-CG has the characteristics of a slow release preparation.

Slow release carbamazepine seems to have several advantages over standard formulations, and should be considered in children with poorly controlled seizures. Some of the advantages could benefit new patients, as lower peak concentrations and reduced interdose fluctuations in plasma concentrations result in fewer of the adverse side effects (including impaired cognitive function). The same may apply to well controlled patients who have side effects. In addition, the pharmacokinetic profile of this preparation suggests the possibility of once daily dosage. For this to be effective the daily dose would probably have to be increased, and it would be advantageous to give the dose at night (2000) to benefit from the slower absorption observed at this time. ${ }^{20}$ Night dosing would help to minimise adverse side effects (as the patient would be asleep) yet would ensure high plasma concentrations of carbamazepine during a period of high susceptibility to seizures (on waking). Adequate plasma concentrations would be maintained throughout the dose interval because of an appreciable increase in the apparent half life of carbamazepine in patients at steady state receiving slow release carbamazepine-CG (R Hartley, S W Ryan, I Forsythe, et al, unpublished observations). Once daily doses of slow release carbamazepine$D$ have been used successfully in children, mainly those receiving several drugs, but with a comparatively large fluctuation in blood concentration (M Albani, B Sehringer-Mansour, unpublished observations)

1 Gamstorp I. Treatment with carbamazepine: children. Adv Neurol 1975;11:237-48.

Eeg-Oloffson $O$. Carbamazepine in childhood seizures. Dev Med Child Neurol 1978;20:680-1.

3 Forsythe WI, Prendergast MP, Toothill C, Broughton PMG. Carbamazepine serum levels in children with epilepsy: a
micro-immunoassay technique. Dev Med Child Neurol micro-immuno

4 Forsythe WI, Sills MA. One drug for childhood grand mal: medical audit for three year remissions. Dev Med Child medical audit for thr

5 Troupin JS, Green JR, Levy RH. Carbamazepine as an anticonvulsant. A pilot study. Neurology 1974;24:863-9.

6 Jeavons PM. Choice of drug in epilepsy. Practitioner 1976; 219:542-6.

7 Forsythe I, Hartley R, Lucock M, McLain B, Ng P. Diurnal 
variation of carbamazepine plasma levels in epileptic chilvariation of carbamazepine plasma levels in epileptic children at steady state: clinical imp.
tions. Ir F Med Sci 1988;157:278.

8 Hoppener RJ, Kuyer A, Meijer JWA, Hulman J. Correlation between daily fluctuations of carbamazepine serum levels
and intermittent side effects. Epilepsia 1980;21:341-50.

9 Tomson T. Interdosage fluctuations in plasma carbamazepine Tomson T. Interdosage fluctuations in plasma carbamazepine concentration determine

10 Hartley R, Lucock M, Forsythe WI, Smithells RW. Solidphase extraction of carbamazepine and two major metabolites from plasma for analysis by HPLC. Foumal of Liquid Chromatography 1987;10:2393-409.

11 Kramer G, Besser R, Katzman K, Theisohn M. Slow release carbamazepine in the treatment of epilepsy. 1 . Comparison of serum level profiles of conventional carbamazepine and slow-release carbamazepine. Acta Neurol 1985;12:70-4.

12 Sivenius J, Heinonen $\mathrm{E}$, Lehto $\mathrm{H}$, et al. Reduction of dosing frequency of carbamazepine with a slow-release preparafrequency of carbamazepine with a
tion. Epilepsy Research 1988;2:32-6.

13 Stefan H, Schafer H, Kuhnen C, Schneider S. Clinical monitoring during carbamazepine slow-release, once-daily (1988:29:571-7.

14 Neuvonen PJ. Bioavailability and central side effects of diffe- rent carbamazepine tablets. Int $\mathcal{f}$ Clin Pharmacol Ther Toxicol 1985;23:226-32.

15 Larkin JG, McLellan A, Munday A, Sutherland M, Butler E Brodie MJ. A double-blind comparison of conventional and Brodie MJ. A double-blind comparison of conventional and controlled-release carbamazepi
Pharmacol 1989;27:313-22.

16 O'Dougherty M, Wrights FS, Cox S, Walson P. Carbamazepine plasma concentration. Relationship to cognitive impairment. Arch Neurol 1987;44:863-7.

17 Aldenkamp AP, Alpherts WCJ, Moerland MC, Ottevanger N, Van Parys JAP. Controlled release carbamazepine: cog nitive side effects in patients with epilepsy. Epilepsia 1987; 28:507-14

18 May T, Rambeck B. Fluctuations of carbamazepine concen trations during the day for two slow-release preparations. Ther Drug Monit 1989;11:21-4.

19 Loonen AJM, Toll PJJM, Nijdam JR. A comparison of carbamazepine divitabs with carbamazepine normal formulation in psychiatric and oligophrenic patients. Phar Weekbl (Sci) 1989;11:23-6.

20 Tedeschi G, Cenraud B, Guyot M, et al. Influence of food on carbamazepine absorption. In: Dam M, Gram L, Penry JK, eds. Advances in epileptology: XIIth Epilepsy Interna-
tional Symposium. New York: Raven Press, 1981:563-7. 